\title{
A lifetime with gloves: \\ Contact dermatitis case presentation
}

\section{Eldivenle bir ömür: Kontakt dermatit olgu sunumu}

\section{idizzet Fidanci ${ }^{1}$}

\section{Özet}

Kimyasalların her alanda kullanımının denetimsiz ve kontrolsüz artması nedeniyle allerjik veya inflamatuar deri reaksiyonu olarak tanımlanan kontakt dermatit sayısında artış gözlenmektedir. Kimyasal çeşitliliğinin artmasıyla tedavide zorluklar yaşanabilmekte ve hastalarda psikolojik rahatsızlıklara neden olabilmektedir. Olgumuzda, Aile Hekimliği Polikliniğimize başvuran, el ve ayaklarında kaşıntılı lezyonları tedavi edilemeyen hastayı sunduk.

Anahtar Kelimeler: Kontakt dermatit, koruyucu eldiven, psikoloji

\footnotetext{
1) Kıbrıs Aile Să̆lığ Merkezi, Aile Hekimliği Uzmanı, Ankara
}

\author{
İletişim adresi: \\ Uzm. Dr. İzzet Fidanc1
}

izzetfidanci@gmail.com

\section{Summary}

There is an increase in the number of patients with contact dermatitis, defined as an allergic or inflammatory skin reaction, due to the unregulated and uncontrolled increase in the use of chemicals in every field. Increased chemical diversity can lead to difficulties in treatment and psychological problems in patients. Here, we report the case of a patient who presented to our Family Practice Clinic with untreatable, itchy lesions on the hands and feet.

Key Words: Contact dermatitis, protective glove, psychology
Gelis tarihi: $03 / 02 / 2020$

Kabul tarihi: $18 / 03 / 2020$

Yayın tarihi: $25 / 03 / 2020$ 


\section{Introduction}

Although some gene mutations play a role in the pathogenesis of contact dermatitis, its incidence increases with industrial development. ${ }^{(1)}$ Frequent use of additives, preservatives, and coloring agents increases the said incidence. Allergic contact dermatitis is an allergic or inflammatory skin reaction, which can occur owing to various foreign substances that come in contact with the skin. The disease is particularly more prevalent among people with certain occupations.

Currently, there is a need for more effective and newer treatment methods for treating allergic contact dermatitis. In this respect, topical treatments, systemic treatments, and treatment methods that involve the combination of topical and systemic treatments and measures required for disease prevention are the main topics that should be discussed. ${ }^{(2,3)}$

To draw attention to the increase in the number of chemicals and the fact that skin diseases can cause psychiatric disorders, we report the case of a patient with untreated contact dermatitis who wore gloves as a protection measure.

\section{Case}

A 51-year-old female patient who presented to our family medicine outpatient clinic with itching and lesions on the hands and feet that persisted for 6 months had no known disease; full physical examination is normal and her blood test results showed no values beyond the normal range. The patient was referred to the dermatology department after she showed no response about 3 months to the administered topical medication 3 times a day (tazarotene, mometasone furoate, betamethasone + salicylic acid, calcipotriol + betamethasone, clobetasol propionate, methylprednisolone aceponate) and oral antihistamines (levocetirizine $5 \mathrm{mg}$, ebastine $10 \mathrm{mg}$, and pheniramine $22.7 \mathrm{mg}$ ) 2 times a day

\section{(Figure 1).}

Hand punch biopsy was performed in the dermatology outpatient clinic. Macroscopic findings: 1 creamcolored $3 \mathrm{~mm}$-deep punch biopsy material contained a skin ellipse of $6 \mathrm{~mm}$ diameter; microscopic findings: changing hyperkeratosis and vertical parakeratosis foci were observed. Loss was observed in the granular layer of the focal region. Considering these results, the patient was diagnosed with psoriasiform spongiotic dermatitis.

In the report, as a comment, it was recommended to evaluate the patient for contact dermatitis in the chronic phase, and the patient was admitted to the dermatology service and monitored for 10 days. The topical medications applied during follow-ups did not provide any remission in the lesions. Etiology could not be determined, and the patient was discharged with the recommendation to wear gloves, which do not contain any allergens or additional constituents.

The patient presented to the psychiatry department as her condition could not be treated and she was extremely uncomfortable with wearing gloves; she was administered an anxiolytic (Buspirone $\mathrm{HCl} 5 \mathrm{mg}$ ) and antidepressant (Venlafaxine $\mathrm{HCl} 37.5 \mathrm{mg}$ ) once a day. She had lost hope of recovering and expressed that her will to live was diminishing, and the patient had a pessimistic mood.

\section{Discussion}

Increase in the number and diversity of chemicals owing to industrial development is associated with several diseases and particularly skin diseases. As demonstrated in the study by Ada et al. evaluating skin patch test results, there was a great diversity of chemicals and the chemicals differed even across cities within a country. ${ }^{(4)}$ As shown in the patch test results by Tunali et al., test results could even change daily ${ }^{(5)}$ and the reason 
why the etiologic agent could not be identified in our case possibly is the increased chemical diversity and the lack of diagnostic methods for defining etiology.

The diagnostic criteria for Allergic Contact Dermatitis are as follows; patient's history (contact presence of substance), physical examination (allergic lesions) and skin patch test. Skin patch test in patients it is the most important tool used to confirm the diagnosis. The positivity of the test is age, gender, presence of atopy, series used and change according to the characteristics of countries and regions It can vary. ${ }^{(6)}$ In our case, the skin patch test was positive next to the clinic, and the pathology report supported the diagnosis.

Psychodermatologyis a term, which arose from the relationship between the skin and brain both of which originate from the same germ layer (ectoderm) in the embryo. As stated in the article by Mercan and Kıvanç Altunay, there can be conditions, which require collaboration with the psychiatry department for dermatologic patients. ${ }^{(7,8)}$ Holistic approaches, such as the biopsychosocial approach commonly used in family medicine, should not be forgotten in other departments. This was also applicable in our case; the cooperation between the psychiatry and dermatology departments would be more beneficial for such patients. Similarly, in the study by Güz et al., it was demonstrated that psychological disorders such as obsessive-compulsive symptoms, alexithymia, depression, and anxiety were considerably more prevalent in patients with psoriasis, urticaria, and alopecia. ${ }^{(9)}$

\section{Conclusion}

There is an uncontrolled increase in the use of chemicals in parallel with the unregulated industrial development, which is accompanied by an increase in the incidence of chemical-induced diseases and in particular skin diseases.

Moreover, the treatment of such diseases becomes more challenging with the increase in chemical diversity. Updates should be made in the treatment methods of untreatable diseases that affect patients' daily quality of life, and it should be considered that psychological problems can be observed in these patients if such updates are not made. In this context, thanks to the holistic approach of family medicine, it is important for the skin lesions to evaluate all systems together, especially psychiatric evaluation, and follow-up.

\section{Figure 1: Hyperkeratotic lesions in hands and feet}
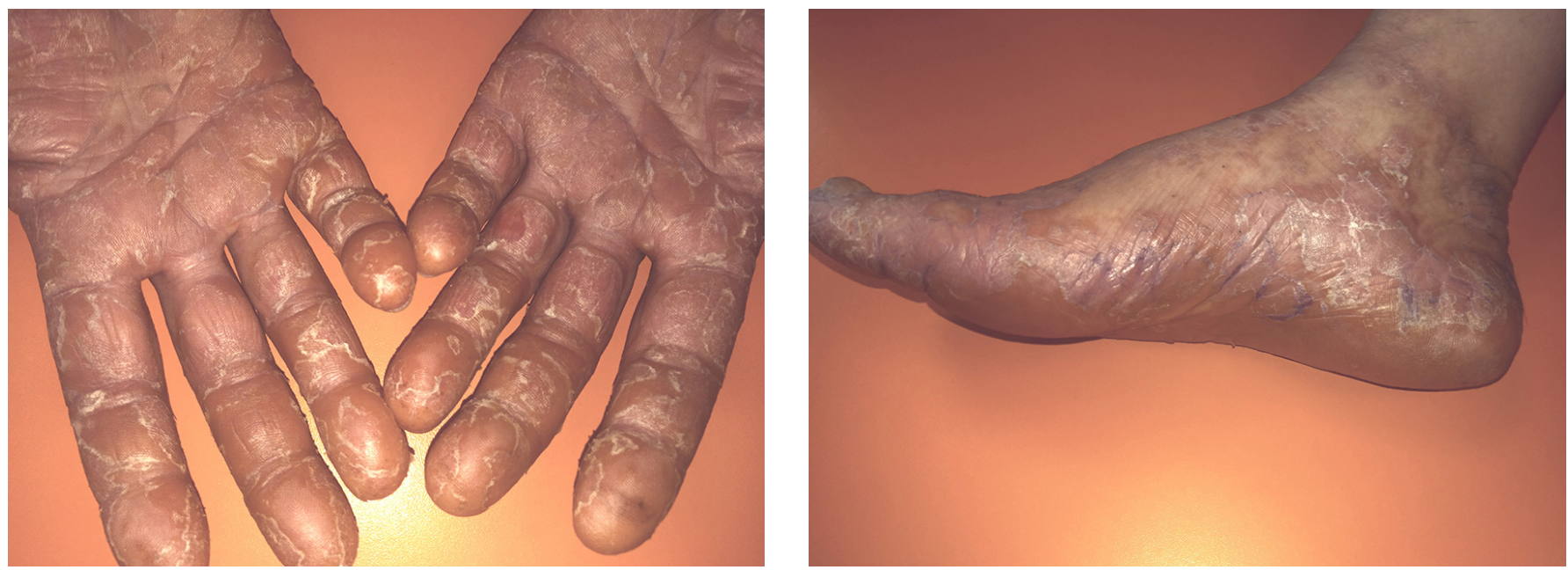


\section{Kaynaklar}

1. Handa S, Khullar G, Pal A, Kamboj P, De D. Filaggrin gene mutations in hand eczema patients in the Indian subcontinent: A prospective case-control study. Contact Dermatitis 2019 Jun;80(6):359-64. doi: 10.1111/cod.13233.

2. Akyol A. Allerjik Kontakt Dermatit Tedavisi. T Klin Allerji-Astım 1999; 1(1): 22-6.

3. Saint-Mezard P, Rozie'res A, Krasteva M, Be'rard F, Dubois B, Kaiserlian D, Nicolas JF. Allergic contact dermatitis. Eur J Dermatol $2004 ; 14(5)$ : 284-95.

4. Ada S, Aşkın Ü, Güleç AT, Seçkin D. Alerjik Kontakt Dermatit Tanısıyla Deri Yama Testi Yapılan 775 Hastanın Sonuçları. Türkderm 2010; 44(4): 187-92.
5. Tunalı Ş, Acar A, Sarıcıoğlu H, Palalı Z, Tokgöz N. Kontakt Dermatitli 400 Hastada Yama Testi Sonuçları. Turkiye Klinikleri J Dermatol. 1995;5(2):71-7.

6. Çalka Ö, Karadağ AS, Akdeniz N, Güneş Bilgili S. Türkiye'nin Doğusunda Kontakt Dermatitli Hastalarda Deri Yama Testi Sonuçları. Turkderm 2011; 45(1): 19-23.

7. Mercan S, Altunay İK. Psikiyatri ve Dermatolojinin Ortak Çalışma Alanı: Psikodermatoloji. Türk Psikiyatri Dergisi 2006; 17(4):305-13.

8. Altunay İK. Psikodermatoloji tarihçesi ve genel bakış. Turkderm 2010; 44(1): 4-6.

9. Güz H, Ay M, Dilbaz N. Bir Grup Dermatolojik Hastalarda Aleksitimi, Depresyon ve Anksiyete. Düşünen Adam 2000; 13(3): 161-5. 